\title{
THE PROJECT: \\ Financial Instability and Overvaluation of the Exchange Rate in Latin America: Analysis and Policy Recommendations
}

\author{
PROJECT PROPOSAL TO THE FORD FOUNDATION BY THE CENTER \\ FOR DEVELOPMENT MACROECONOMICS OF THE SCHOOL OF \\ ECONOMICS OF SÃO PAULO OF GETULIO VARGAS FOUNDATION
}

The present Global Crisis began as a banking crisis that turned into a major economic crisis. It took the world by surprise, because politicians, businessmen and economists believed that they had learned with 1930s Great Depression. The Keynesian revolution, the strengthening of central banks, the development of full regulatory system, and the creation of the Breton Woods institutions proved such learning. They had a definite objective: to avoid new major financial crises. Yet, since the 1970s, economists engaged in de-learning or forgetting what they have learned. They relegated Keynesian macroeconomics to the margin and deregulated financial markets. In consequence, since the early 1980s financial crises multiplied in the central and in the developing economies, but only in the later they were disastrous as, for instance, the 1980s Latin-American debt crisis, or the 2001 Argentinean crisis. In the central countries they happened but were relatively mild. But suddenly a banking crisis that began in the United States with the default of subprime mortgages in 2007 turned into bank failures and into panic in October 2009. A consensus was established very soon that this was the worst economic crisis since the 1930s. It will be a crisis that probably will live with us for many years despite the strong and reasonably competent economic policies with which governments responded to it.

In this crisis, developing countries suffered less. All of them saw their growth rates to be reduced and, in several cases, turned negative, but while all rich countries were strongly hit by the crisis, major losses among middle income countries only occurred in the ones that had become highly indebted recently like some East European countries, or, being industrial economies, depended too much on oil 
exports like Russia, or had their economy too much dependent on the American economy like Mexico. This lighter impact is not surprising in relation to Asia, but it is in relation to Latin America that has a long history of recurrent financial crises.

\section{Objectives}

The most general target of this project is to study financial instability in Latin America and particularly the impacts in Brazilian economy. In order to be more specific, this project will involve two conferences, and our two main objectives will be to discuss in the first conference: (1) how will change the world economy and Latin America in consequence of the global financial crisis; and (2) the nature of financial crises that haunted Latin America in the recent past and search for the policies that should be adopted to avoid them. A third objective that will be the subject of the second conference is to study the relations between financial instability, the exchange rate and deindustrialization in Brazil.

\section{Financial crises in Latin America}

The first objective is relevant. The world economy will change; the economic center of the world will change to the East; the dollar will lose relative power as reserve money; nationalism will increase; regulation of financial markets will increase; financial flows will most likely be reduced. Yet, although these facts will have strong impact on Latin-American economies and we will discuss them, the main focus of the project will not be in these themes because they are not specific to Latin America. Our main concern will be to offer responses to the second objective. The assumption or hypothesis is that usually financial crises in Latin America are not banking crises as the present one is, but are balance of payment or exchange rate crises - crises that happen in countries that are not indebted in their own money, but in other countries' money. Thus, when a developing country follows the growth with foreign savings policy, it incurs in overvaluation of the exchange rate and in recurrent and high current account deficits; it becomes heavily indebted; creditors eventually lose confidence, suspend the rolling over of the foreign debt, and the country defaults - what will cause a sudden stop in capital inflows and sharp devaluation of the currency.

In this project, our assumption is that there is a tendency to the overvaluation of the exchange rate - and that this tendency or the overvalued currency is a major factor not only in causing balance of payment crisis but also artificially high real wages, artificially high consumption, low domestic savings, and low growth rates.

In this project, we will, first, verify if this is really so: if financial crises in Latin America are not mainly or originally banking crises (crises that originate in poor lending on the part of domestic banks), but are balance of payment crises that also originate in poor lending - lending made by banks of the rich countries, in their own currencies, to firms and governments in the developing countries. These crises 
break up when the foreign banks (that are not yet threatened of going bankrupt) feel uneasy on continue lending to the developing country, lose confidence, and suspend the rolling over of a debt often when the country is already involved in Ponzi finance: it does not generate hard currency even to pay current interests on the foreign debt.

Second, given that financial crises are recurrent in Latin America, we will see if there is certain regularity in the balance of payment crises. Or, in other words, if developing countries, and, among them, Latin-American countries tend systematically to incur in high foreign indebtedness, following a cycle. Our hypothesis is that they do.

Third, we will discuss the reasons for this. Is it true that this foreign indebtedness and recurrent balance of payment crises derive from the recurrent public deficits or fiscal largess or fiscal populism, as the dominant economic literature asserts, or, alternatively, it derives from recurrent current account deficits, or from the growth with foreign savings policy? For sure, we can escape from this question by assuming the twin deficits hypothesis. But, do twin deficits (public and current account) always happen? Or may national economies have current account deficits without incurring in public deficits because an overvalued exchange rate causes excess foreign demand and increasing private indebtedness?

Fourth, we will discuss a key hypothesis: that there is a tendency to the overvaluation of the exchange rate in developing countries. The exchange rate does not fluctuate nicely around the line of intertemporal equilibrium of the current account, as orthodox economists would predict; nor is just volatile, as less orthodox economists widely recognize; but this volatility has a sense: it tends to appreciation or overvaluation. Thus, unless economic policy neutralizes such tendency, the economy will face increasing current account deficits, foreign indebtedness, and eventually crisis or default on the foreign debt. In this moment the exchange rate sharply depreciates, and a new cycle begins.

Fifth, if this hypothesis makes sense, we should look for its causes, but before discussing the causes of the tendency, we must discuss what an equilibrium exchange rate is. In principle, it should be the exchange rate that equilibrates intertemporally the current account. Yet, if the country faces the Dutch disease, the real equilibrium exchange rate will be the one that makes competitive industries utilizing technology in the state of the art or in production efficient frontier: the industrial equilibrium exchange rate.

Sixth, we should discuss the causes of the overvaluation of the exchange rate in developing countries. The Dutch disease is a structural cause that explains part of the overvaluation, the one that implies the transition from the industrial to the current equilibrium exchange rate. At this level the exchange rate makes unviable economically tradable industries utilizing technology in the state of the art, but do not cause current account deficit. Thus, we need a second structural cause to explain why the exchange rate tends to get more appreciated than the one corresponding to the current equilibrium. This cause is the fact that higher profit and interest rates usually existing in developing countries attract capital inflows that addition- 
ally appreciate the national currency. More important than this second structural cause, however, are the policy causes that additionally attract foreign capitals: the growth with foreign savings policy, the adoption of nominal (exchange rate) anchors to fight inflation, the use of exchange rate appreciation in capital targeting policies to meet the target, capital deepening policy (to increase the interest rate) policies, and, finally, "exchange rate populism": the practice often adopted by politicians of appreciating the exchange rate to lower inflation, increase real wages and consumption, and get reelected if the ensuing balance of payment crisis does not take place before the election date.

Seventh, once we reasonably agree on the previous hypothesis, we must ask for evidence. First, to survey the existing evidence - the previous econometric studies that did not have behind the tendency to the overvaluation of the exchange rate hypothesis but sustain it; second, new evidence, out of new research.

Eight, we will ask for policy recommendations. Recommendations at national level related to the neutralization of the Dutch disease and the administration of the exchange rate; recommendations at the international level, as, for instance, an international agreed cap on current account deficits, and an international institution (possibly the IMF) monitoring the current account deficits and signaling when the country surpasses the cap.

This is essentially an economic theory and economic policy project, but, besides economists, we will ask political scientists to participate because, for instance, in the discussion of the causes of overvaluation and crises related either to excessive lending-borrowing or to exchange rate populism, we are interested also in the political questions involved. Second, when we discuss policy recommendations, we also need political scientists and international relations specialists to participate in the discussion.

\section{Deindustrialization in Brazil?}

Latin America is our object of study, but we will provide a special attention to Brazil because it is the greatest country of the region and because the majority of the researchers that will participate are Brazilians. Brazil is a middle income country counting with a large manufacturing industry that since the early 1990s is being threatened by deindustrialization. First, we have to confirm this fact, because, besides the existence of data showing the fact, there is still discussion on the theme. Would it be a premature deindustrialization, or a normal one, as it is happening in developed countries? Second, which is the relation of it with financial instability, and, particularly, with the opening of foreign accounts in the early 1990s and the overvaluation of the exchange rate?

Although the Brazilian economy is often presented as one of the BRICs and as an example of success, we are persuaded that this view is mistaken. In the last ten years Brazil's growth was one third of the other BRIC countries' growth, and not considering the present global crisis, it fell in two balance of payment crisis, Russia in one, and China and India, in none. Why it happened? Is it reasonable to think 
that the destiny of China is to be the world's factory whereas Brazil will be the world's farm? What is the relation of this possibility to the higher financial instability and considerably lower rates of growth when compared to China? The answer will not be very different from the more general one given in relation to financial instability in Latin America and its relation to the high leverage not only of the public but mainly of the private sector. Yet, we will have to be more specific in this case.

\section{The Center of Structuralist Development Macroeconomics}

The Center of Structuralist Development Macroeconomics of the São Paulo School of Economics of Getulio Vargas Foundation is a small research center that aims to study the relation between macroeconomics and development economics and to recommend economic policies seeking for higher life standards, full employment and stability. Their researchers concentrate efforts in the definition of the "new developmentalism" and the search for empirical evidences of the well-succeeded catching-up reached by countries that follow a national development strategy, like the Asian ones. The workshops and the conference included in this project, as much as the book we intend to publish with the papers presented and discussed on them, will decisively help to disseminate this view and to formulate a proposal of global financial governance and a consistent national development strategy in Latin-American countries in the post-crisis scenery.

Luiz Carlos Bresser-Pereira Project coordinator 